\title{
PENGARUH LATIHAN PITCHING SLINGSHOT JARAK TETAP DAN \\ BERTAHAP TERHADAP HASIL PITCHING SOFTBALL MAHASISWA SEMESTER 4 PJKR UNWAHAS \\ TAHUN 2017/2018
}

\author{
Noviantoro Dwi Nugroho, Dr. Kardiyono, M. Pd., Yudhi Purnama, M. Pd. \\ Dosen Prodi Pendidikan Jasmani Kesehatan dan Rekreasi \\ Fakultas Keguruan Ilmu Pendidikan Universitas Wahid Hasyim Semarang
}

\begin{abstract}
The purpose of this research is to know: The effect of constant range on the pitching slingshot exercise to the pitching softball result. The effect of gradual range on the pitching slingshot exercise to the pitching softball result. The different effect between constant and gradual range of pitching slingshot exercise against the pitching softball exercise. Based on the result of the constant range of pitching slingshot exercise data calculation obtained average score of pretest 7,91 points and posttest 12,91 points with probability value of $(p)=0,000(<0,05)$ there is efect on constant pitching slingshot exercise. Meanwhile, calculation of gradual pitching slinghsot exercise obtained average score of pretest 7,916 points and posttest 14,333 points with probability $(p)=(0,000)(<0,05)$ there is effect on gradual pitching slingshot exercise. Calculation from both two exercise methods obtained average score of 12,91 points and 14,333 points, there is significant efect difference between the two excercise against the pitching softball result with conclusion on the effect of gradual range is higher with precrntage of 53,46\%, while gradual pitching slingshot exercise only obtained 41,66\%.
\end{abstract}

Key Word : Pitching Slingshot exercise, Pitching Softball exercise 


\section{PENDAHULUAN}

Dewasa ini, permainan olahraga berkembang sangat pesat, banyak olahraga-olahraga baru bermunculan dan masuk ke Indonesia dengan peminat yang tidak sedikit. Banyak orang awalnya penasaran dengan salah satu dari olahraga permainan tersebut dan tidak sedikit yang akhirnya menekuni olahraga permainan tersebut. Namun tidak sedikit cabang olahraga permainan dari dulu yang sangat populer dan banyak sekali peminatnya, misalnya Sepakbola, bola basket, bola voli, dll. Namun kepopuleran cabang olahrga permainan tersebut tidak terjadi pada cabang olahraga permainan yang sudah lama masuk Indonesia, seperti Baseball dan Softball. Kedua cabang ini merupakan salah satu cabang unggulan tim nasional Indonesia dikancah Internasional. Namun yang menjadi masalah adalah sepinya peminat cabang olahraga ini.

Universitas Wahid Hasyim Semarang merupakan salah satu perguruan tinggi yang ikut memperkenalkan dan mempopulerkan cabang olahraga softball. Itu dibuktikan dengan adanya mata kuliah softball dalam perkuliahan mahasiswa FKIP, prodi PJKR. Selain itu, Universtitas Wahid Hasyim juga membentuk UKM (Unit Kegitan Mahasiswa) Softball. Dengan cara sederhana itu, mahasiswa Universitas Wahid Hasyim Semarang lebih mengenal dan mengetahui apa itu softball. 
Softball adalah permainan beregu yang menggunakan bola dan pemukul, dan sebenarnya merupakan penyederhanaan dari permainan baseball. Permainan ini pertama kali diciptakan oleh George Hancock yang berasal dari kota Chicago pada tahun 1887. Sebelumnya softball dimainkan dilapangan tertutup. Oleh karena itu ukuran lapangannya hanya seluas duapertiga lapngan baseball. Bola yang digunakan dalam permainan softball pun lebih lunak dibanding bola baseball.

Pada tahun 1930 Softball mulai dimainkan di lapangan terbuka, dan turnament tingkat nasional di Amerika Serikat untuk pertamakalinya diselenggarakan di Chicago pada tahun 1993. Tahun 1950 permainan ini mulai di kenal secara luas dan dipertandingkan di tingkat internasional. Sampai saat ini softball telah dimainkan di lebih dari 50 negara, dan secara khusus permainan ini sangat digemari di Amerika, Jepang, Cina, Selandia Baru dan Australia. Kejuaraan dunia softball putri diselenggarakan untuk pertamakalinya pada tahun 1965 di Melbourne Australia, Sementara kejuaraan dunia softball putra baru diselenggarakan satu tahun kemudian, yaitu tahun 1966 di Mexico City.

Di Indonesia pada umumnya, pemasalan cabang olahraga ini belum menunjukan perkembangan yang menggembirakan. Terdapat beberapa hal yang diduga sebagai penghambat perkembangan dan penyebab kurang populernya permainan ini bagi masyarakat di Indonesia, di antaranya perlengkapan dan peralatan yang digunakan dalam permainan ini harganya relatif mahal untuk sebagian besar masyarakat Indonesia, sehingga hanya kalangan tertentu yang mampu membeli. Selain itu, Peraturan serta teknik dan taktik permainan softball sangat rumit dan bersifat individual, artinya setiap posisi pemain dalam permainan ini memiliki aturan tersendiri sehingga secara keseluruhan permainan ini kurang enak ditonton dan tidak mudah dinikmati oleh mereka yang belum memahami peraturan permainannya. Selanjutnya, banyak istilah teknis di dalam permainan ini yang harus dipahami dan diucapkan dengan 
menggunakan bahasa asing (Inggris), dan hingga saat ini istilah-istilah tersebut belum memungkinkan untuk diterjemahkan ke dalam bahasa Indonesia, dan kurangnya fasilitas penunjang, khususnya lapangan. Sebagaimana peralatan lain yang digunakan, lapangan softball yang standard memiliki bentuk yang unik dan memerlukan biaya besar untuk membangun serta membutuhkan penanganan yang khusus untuk perawatannya. Lapangan-lapangan yang umum seperti lapangan sepakbola atau tanah lapang luas yang selama ini dapat digunakan, hanya dapat untuk melatih keterampilan dasar saja. Sementara untuk meningkatkan prestasi dan bertanding, harus dilakukan di lapangan standart yang memang memenuhi persyaratan untuk itu. Selain itu semua, terbatasnya jumlah dan jenis literatur tentang softball yang disajikan dalam bahasa Indonesia menghambat perkembangan dan minat bagi masyarakat Indonesia untuk mempelajari dan menggeluti olahraga ini.
Mahasiswa Universitas Wahid Hasyim Semarang, khususnya Fakultas Keguruan dan Ilmu Pendidikan Prodi PJKR diwajibkan mengambil mata kuliah softball, oleh karena itu semua mahasiswa Prodi PJKR diwajibkan menguasai teknikteknik dasar permainan softball, termasuk teknik dasar lemparan pitching. Mayoritas mahasiswa Prodi PJKR Universitas Wahid Hasyim Semarang baru mengenal permaianan softball, hal itu berimbas kepada teknik dan pengetahun dasar mengenari permainan ini sangat terbatas, hal itulah yang membuat dosen merasa bingung bagaiamana cara memberikan latihan yang tepat kepada mahasiswa dengan kondisi seperti ini.

Teknik dasar merupakan hal yang paling berpengaruh terhadap prestasi, oleh karena itu mahasiswa atau atlet yang ingin berprestasi harus menguasai dengan baik dna benar teknik dasar permainan softball. Salah satu teknik dasar yang harus di kuasai adalah teknik melempar, teknik melempar ada berbagai macam jenisnya, yaitu lemparan atas kepala (overhead 
throw), lemparan samping (side arm throw), lemparan bawah (under hand toss), lemparan umpan (pitching).

Untuk lemparan atas kepala, lemparan samping, dan lemparan bawah wajib dikuasai oleh semua pemain softball, sedangkan untuk lemparan umpan (pitching) hanya dikuasai oleh beberapa pemain saja yang mempunyai spesialisasi melempar dan memiliki kemampuan lebih untuk melakukannya. Untuk memnguasai teknik lemparan umpan (pitcing) seorang pemain harus memiliki power atau kekuatan dan akurasi yang baik agar mendapatkan lemparan yang tepat sasaran serta sulit untuk di pukul oleh pemukul lawan. Karena tujuna utama melakukan lemparan pitching adalah untuk melemparkan bola tepat pada catcher namun sulit dipukul oleh batter dan akhirnya menghasilkan strike sampai akhirnya mematikan seorang batter.

Dari paparan di atas, peneliti memutuskan untuk memecahakan masalah tersebut dengan meneliti tetntang pengaruh latihan lemparan pitching slingshot jarak tetap (jarak sebenranya) dengan jarak bertahap untuk melatih kemampuan melakukan lemparan pitching mahasiswa PJKR unwahas semester 4.

Dalam penelitian ini, peneliti melakukan penelitian eksperimen dengan cara membagi sampel menjadi 2 kelompok, antara lain kelompok latihan jarak tetap dan kelompok latihan jarak bertahap.

\section{METODE PENELITIAN}

Metode yang digunakan adalah metode desriptif dengan penekatan kuantitatif. Pengertian metode deskriptif diungkapkan dalam buku Prosedur Penelitian oleh Arikunto (2010:3) bahwa Penelitian deskriptif adalah penelitian yang dimaksudkan untuk menyelidiki keadaan, kondisi, situasi, peristiwa, kegiatan, dan lainlain.

Penelitian metode kuantitatif diungkapkan dalam buku Metode Penelitian oleh Sugiyono (2010:14) yaitu sebagai berikut : penelitian kuantitatif adalah metode penelitian yang berdasarkan pada filsafat positivisme, digunakan untuk meneliti pada populasi atau sampel tertentu, pengumpulan data 
menggunakan instrumen penelitian, analisis dan bersifat statistik, dengan tujuan untuk menguji hipotesis yang telah ditetapkan.

Sedangkan rancangan dalam penelitian ini adalah pretest postest design, karena pada desain ini terdapat pretest sebelum diberikan treatment dengan demikian hasil treatment diketahui lebih akurat karena dapat membandingkan dengan keadaan sebelum diberi treatment (Sugiyono:110)

\section{HASIL PENELITIAN}

1.) Metode pengumpulan data dalam penelitian ini adalah dengan menggunakan metode eksperimen dengan teknik tes dan pengukuran. Menurut Sugiyono (2010:107) metode penelitian eksperimen dapat diartikan sebagai metode penelitian yang digunakan untuk mencari pengaruh perlakuan tertentu terhadap yang lain dalam kondisi yang terkendalikan.

Dalam metode pengumpulan data ini dilakukan dengan tes yaitu : 1.) Tes pitching slingshot kelompok latihan jarak tetap. 2.) Tes pitching slingshot kelompok latihan jarak bertahap. 3.) Tes hasil pitching slingshot pada jarak sebenarnya.

2.) Dari hasil uji Normalitas yang dilakukan pada kelompok jarak tetap diperoleh nilai probabilitas 0,200 dimana nilai tersebut lebih besar dari $0,05 \quad(5 \%)$ dengan demikian maka disimpulkan bahwa data kelompok jarak tetap berdistribusi normal. Sedangkan data hasil uji normalitas pada kelompok jarak bertahap diperoleh nilai probabilitas 0,200 dimana nilai tersebut lebih besar dari 0,05 (5\%) dengan demikian maka disimpulkan bahwa data kelompok jarak bertahap berdistribusi normal.

3.) Dari hasil uji homogenitas varians yang tertera dalam tabel diperoleh nilai probabilitas 0,855 dimana nilai tersebut lebih besar dari 0,05 (5\%) dengan demikian maka disimpulkan bahwa sampel yang digunakan berasal dari populasi yang homogen.

4.) Dari hasil Hipotesis Terlihat dari output SPSS bahwa signifikansi (sig. 2-tailed) adalah 0,000. Karena signifikansi $<\alpha=0,05$. Dengan demikian dapat disimpulkan hipotesis 1 yang berbunyi "Ada 
pengaruh latihan pitching slingshot jarak tetap terhadap hasil pitching softball pada mahasiswa semester 4 Unwahas tahun 2018" dapat

\section{diterima.}

Berdasar tabel di atas juga dapat dilihat selisih antara sebelum dan sesudah yaitu sebesar 5 poin, bila dirubah dalam bentuk persen menjadi $41,66 \%$, dapat disimpulkan bahwa kemampuan lemparan teknik slingshot Softball mengalami kenaikan sebesar $41,66 \%$ dengan pemberian latihan pitching slingshot jarak tetap.

Terlihat dari output SPSS bahwa signifikansi (sig. 2-tailed) adalah 0,000. Karena signifikansi $<\alpha=$ 0,05. Dengan demikian dapat disimpulkan hipotesis 2 yang berbunyi "Ada pengaruh latihan pitching slingshot jarak bertahap terhadap hasil pitching softball pada mahasiswa semester 4 Unwahas tahun 2018 " dapat diterima.

5.) Terlihat dari output SPSS bahwa signifikansi (sig. 2-tailed) adalah 0,000. Karena signifikansi $<\alpha$ $=0,05$. Dengan demikian dapat disimpulkan hipotesis 2 yang berbunyi "Ada pengaruh latihan pitching slingshot jarak bertahap terhadap hasil pitching softball pada mahasiswa semester 4 Unwahas tahun 2018 " dapat diterima.

Berdasar tabel di atas juga dapat dilihat selisih antara sebelum dan sesudah yaitu sebesar 6,416 bila dirubah dalam bentuk persen menjadi $53,46 \%$, dapat disimpulkan bahwa kemampuan lemparan teknik slingshot Softball mengalami kenaikan sebesar $53,46 \%$ dengan pemberian latihan pitching slingshot jarak bertahap.

6.) Berdasarkan hasil dari kedua analisis metode latihan pitching slingshot jarak tetap yang hanya mengalami peningkatan sebesar 5 poin, bila dirubah dalam bentuk persen menjadi $41,66 \%$ sedangkan latihan pitching slingshot jarak bertahap dapat dilihat kenaikan terhadap hasil pitching softball lebih besar dibanding menerapkan metode latihan pitching slingshot jarak tetap yaitu sebesar 6,416 poin, bila dirubah dalam bentuk persen menjadi $53,46 \%$, dengan demikian dapat di simpulkan bahwa latihan pitching slingshot jarak bertahap lebih efektif 
dalam meningkatkan kemampuan pitching softball mahasiswa semester 4 Unwahas 2018 dibanding dengan latihan pitching slingshot jarak tetap.

\section{SIMPULAN}

Berdasarkan dari hasil penelitian dan pembahasannya dapat peneliti simpulkan sebagal berikut: 1.) Ada pengaruh latihan pitching slingshot jarak tetap seebesar $41,66 \%$ terhadap hasil lemparan pitcher softball pada Mahasiswa PJKR semester 4 Unwahas 2018. 2.) Ada pengaruh latihan pitching slingshot jarak bertahap sebesar $53,46 \%$ terhadap hasil lemparan pitcher softball pada Mahasiswa semester 4 Unwahas 2018. 3) Latihan pitching slingshot jarak bertahap lebih berpengaruh sebesar $53,46 \%$ daripada latihan pitching slingshot jarak tetap sebesar $41,66 \%$ terhadap hasil pitching softball Mahasiswa PJKR semester 4 Unwahas tahun 2018.

\section{SARAN}

Dari hasil kesimpulan penelitian maka penulis mengajukan saran sebagai berikut:
1.) Untuk mendapatkan hasil pitching yang bertenaga dan akurat, maka perlu memperhatikan teknik dasar slingshot dengan memberikan basis latihan lemparan secara terprogram.

2.) Saat latihan pitching, perlu menekankan teknik-teknik dasar yang benar dan mudah dipahami, terutama bagi pemain pemula, sehingga mampu menguasai teknik pitching dengan benar dan menghasilkan lemparan yang tepat sasaran.

3.) Bagi peneliti lain yang hendak mengadakan penelitian sejenis, hendaknya menjadikan hasil penelitian ini sebagai bahan referesi agar diperoleh hasil yang lebih optimal. 
Nurhasan. (2005). Aktivitas

Kebugaran. Jakarta:

Direktorat Pembinaan

Ketenagaan Luar Biasa.

\section{DAFTAR PUSTAKA}

Arikunto, S. (2006). Prosedur Penelitian: suatu pendekatan praktek. Jakarta: rineka Cipta.

Darmawan, D. (2013). Metode Penelitian Kuantitatif. Bandung: PT. REMAJA ROSDAKARYA.

David, K. M. (2002). Measurment by the Physical Educator. Walmington.

Gudiyah. (2007). Keterampilan Melempar Atas Bola Softball Anggota UKM Softball Baseball Putera Universitas Negeri Yogyakarta . Skripsi: Universitas Negeri Yogyakarta.

Lutan, R. (2000). Dasar-dasar Kepelatihan . Jakarta: Departemen Pendidikan Nasional Direktorat Jendral Pendidikan Dasar Menengah.

Margono, S. (2005). Metode Penelitian Pendidikan Jakarta: Rineka Cipta.

Muhajir. (2007). Pendidikan Jasmani Olahraga \& Kesehatan SMP Kelas VII. Jakarta: Yudistira.

Noor, J. (2016). Metodologi Penelitian. Jakarta: K E N C A N A.
Purwanto, M. N. (2007). Psikologi Penelitian. Bandung: PT. Remaja Rosdakarya.

Rahayu, T. (2008). Mengenal Permainan Softball. Semarang: KEMENPORA RI.

Rif'iy Qomarullah, S. K. (2012). Metode Pembelajaran Atletik Dasar. Kudus: MASAEIFA Jendela Ilmu.

Sugiyono. (2014). Statistika Untuk Penelitian.

Bandung: Alfabeta.

Suharsimi. (2010). Prosedur Penelitian Suatu Pendekatan Praktik. Jakarta: Rineka Cipta.

Sukadiyanto, P. D. (2005). Pengantar Teori dan Metodologi Melatih Fisik. Yogyakarta: FIK UNiversitas Negeri Yogyakarta.

Suparlan, A. (2008). Modul Pembelajaran Softball. Bandung: FPOK UPI.

Wahjoedi. (2001). Landasan Evaluasi Pendidikan Jasmani. Jakarta: PT Raja Grafindo Persada.

Wahjoedi. (2001). Tes Pengukuran Dalam Pendidikan Jasmani dan Olahraga . Ujung Pandang: BKS. PTN Indonesia Timur. 
Widyastuti. (2013). Softball dan

Baseball. Solo: Aneka Ilmu. 